\title{
Veiledning for elskverdige leger
}

Med over 50000 forskjellige nålevende myggarter på verdensbasis, og omkring 2000 her i Norge, er det heldigvis bare et fåtall som stikker eller biter. Bare noen titalls arter er malariamygg, men rundt halvparten av verdens befolkning bor i områder der malaria forekommer. Pasienter som blir behandlet for malaria i Norge i dag, er smittet i utlandet. Men en gang i tiden oppsto det også lokale utbrudd her til lands, særlig i områdene rundt Oslofjorden. Den gangen gikk sykdommen under navnet klimatfeber eller koldfeber, og det siste kjente utbruddet var i 1870. I Tidsskriftet nr. 14/1925 gjorde marinelege Harald Engelsen rede for utseendet til forskjellig mygg, til hjelp for elskverdige leger som ville sende ham eksemplarer (Tidsskr Nor Lægeforen 1925; 45: 739-40).

\section{Indsamling av mygg.}

\section{Fra H. Engelsen,}

Marinens hygieniske laboratorium, Horten.

Til veiledning for de læger, som er saa elskværdige at sende mig mygg for at bringe klarhet over anofelinernes utbredelse i Norge, tillater jeg mig at gi et par oplysninger.

Malariamyggen (anofeles) er ubetydelig større end den almindelige mygg (culex) og har nogen faa brune flekker paa vingerne, særlig ved disses forkant. Palperne er likesaa lange som stiksnabelen (se tegningen). Culex og andre stikmygg (aëdes) har praktisk talt ikke flekkede vinger, og hunnene har meget kort palper. Disse er dog lange hos hannen og haarklædt i den ytre del. I hvilestilling indtar anofeles en skraastilling mot underlaget og synes at staa paa hodet, mens culex sitter parallelt med dette. De øvrige mygg har som regel ganske korte snabler.

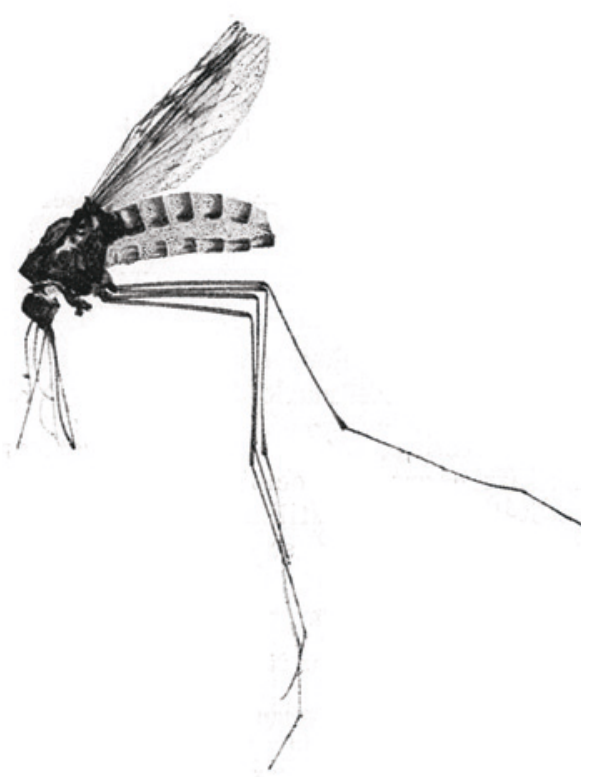

Anopheles maculipennis 9 . Ullensaker

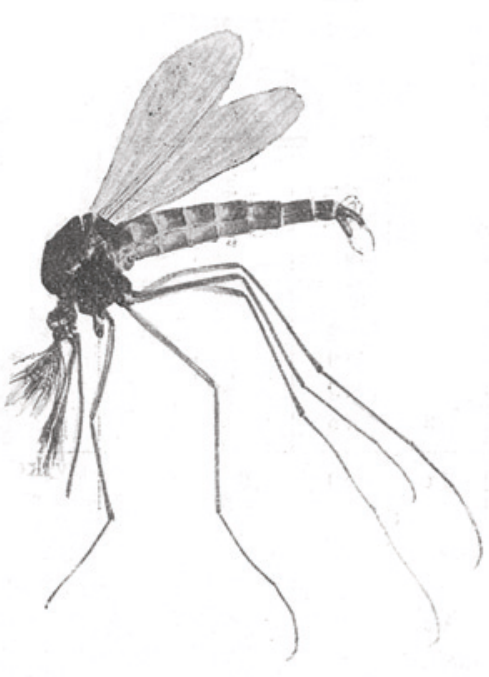

Culex pipiens ơ. Søndmør

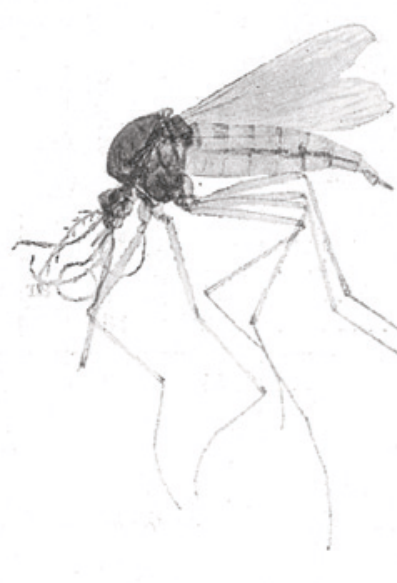

Culex pipiens + . Hallingdal 